To reference this article, please use the following citation:

Easton, S. (2009). The prisoner's right to vote and civic responsibility: Reaffirming the social contract? Probation Journal, vol.56, no. 3, pp. 224-237. 


\section{The prisoner's right to vote and civic responsibility: Reaffirming the social contract?}

\section{Susan Easton, Brunel Law School}

Abstract: This article considers the issue of the prisoner's right to vote in the light of recent developments in law and policy. It critically reviews the purported justifications for disenfranchisement and argues that re-enfranchisement should be pursued on the grounds of both principle and policy.

Keywords: Citizenship, prisoner disenfranchisement, punishment, social contract, voting rights.

\section{Introduction}

The current law in the UK is that convicted prisoners (with few exceptions) are denied the right to vote in national or local elections while they are incarcerated. Remand prisoners, and sentenced prisoners imprisoned for contempt of court and for non-payment of fines, are allowed to vote. The provisions disenfranchising offenders are in s3 of the Representation of the People Act 1969, as amended in 1983 and 2000, which states that:

A convicted prisoner during the time that he is detained in a penal institution in pursuance of his sentence... is legally incapable of voting in any parliamentary or local election.

This denial of voting rights has led to considerable criticism. At a time when the Government is under attack for the erosion of civil liberties and is encroaching on rights across a wide range of issues, including extending pre-charge detention, restoring the right to vote to convicted prisoners would be a positive step in affirming a commitment to fundamental rights. Although critics have focused on rights violations in relation to control orders, extended detention and the treatment of suspects, for example, in the Terrorism Act 2006 and the Counter-Terrorism Bill 2007-08, the rights lost during detention have received less attention but may still be significant.

In this article, I consider the Government's justification for the ban, whether the arguments in favour of disenfranchisement are convincing, and whether the problems raised by the ban will be 
resolved by the Government's limited proposals for change. It will be argued that prisoner enfranchisement would benefit both prisoners themselves and the wider society [1].

Although the right to vote might seem less significant than other rights lost or diminished on imprisonment, nonetheless the right to vote is significant symbolically as a recognition of the prisoner's citizen status, and practically, as part of the process of rehabilitation. The Government has been forced to address this issue, as the loss of voting rights for convicted prisoners was successfully challenged in 2005 in Hirst v UK (No. 2) (2006) 42 EHRR 41 in the European Court of Human Rights. The Strasbourg Court held that the UK's automatic and 'blanket ban' breached Article 3 of Protocol No. 1 to the European Convention on Human Rights, which imposes an obligation on states to hold free elections under conditions which will ensure the free expression of the people in the choice of the legislature. Although the Court accepted that a wide margin of appreciation should be given to states, and that the rights under Article 3 of Protocol No. 1 were not absolute, it ruled that a blanket voting ban for all convicted prisoners fell outside the margin of appreciation.

Hirst had already completed the punitive part of his discretionary life sentence but was not allowed to vote during the remainder of his sentence, when he was being detained on the ground of public protection because of a perceived risk to the public. Hirst failed in the Divisional Court in an application for a declaration of incompatibility in relation to the provision in s3 of the Representation of the People Act 1983, but succeeded in Strasbourg. The European Court of Human Rights recognized that states that had adopted the Convention varied in their practice some allowed all prisoners to vote, some allowed prisoners in certain categories to vote, while others did not permit it at all. But the Court held that the right should not be casually removed as this would undermine the democratic process, especially as the UK ban excluded thousands of people from voting. The case was referred in October 2005 to the Grand Chamber, which deals with cases raising issues of great importance and questions of interpretation or the application of the Convention [2]. It upheld the earlier decision of the Chamber in 2003.

In the 2005 General Election, the UK government did allow prisoners held on intermittent custody to vote if they were outside the prison on that day, but the numbers involved were 
negligible. But the ruling in Hirst $v$ UK means that the Government will have to amend the legislation. In response to the judgment, the Government published Consultation Papers on this issue in December 2006 (DCA, 2006) and April 2009 (MJ, 2009), and the Government is now considering possible changes, to allow some categories of prisoners to vote. It has engaged in a public consultation process, and is considering possible options, before drafting new legislation. The second Consultation Paper is considering how any proposed changes might be implemented. The Government's proposed option is to determine eligibility to vote on the basis of sentence and it invites views on the appropriate threshold and procedures for voting in prison. The Strasbourg Court had been particularly critical of the fact that the ban was not the result of a reasoned consideration of the issues, so a lengthy consultation process might be seen as a way of meeting this concern.

Cases were brought in Scotland and Northern I reland challenging the legality of the May 2007 elections on the grounds of incompatibility with the European Convention and the Scottish National Party has also been campaigning on this issue. In Smith v Scott [2007] CSIH9 XA33/04 a convicted prisoner denied registration brought a claim against the Electoral Registration Officer. The Scottish Court of Session said the legislation in the RPA could not be read down as Convention compliant and that they intended to make a formal declaration of incompatibility. Lord Abernathy was critical of the length of time the Government has spent responding to Hirst. However, in D.B. [2007] CSOH 73, Lord Malcolm refused to free a prisoner whose licence had been revoked who wanted to vote in the May Scottish parliamentary elections. Traynor and Fisher also brought a legal challenge in the Court of Session in Edinburgh to stop the May 2007 elections proceeding, arguing that they were not Convention compliant, as any changes in response to Hirst would not be made until the autumn Parliamentary session at the earliest. Lord Malcolm acknowledged the incompatibility with Article 3 of Protocol No. 1, but rejected their claim, noting that the Government was taking steps to deal with the problem, but it would take time (Derek Traynor and James Fisher [2007] CSOH 78). A similar case brought in Northern Ireland, by prisoners who were unable to vote in the March Northern Ireland Assembly elections, also failed (Toner and Walsh [2007] NIQB 18). 
Successive UK governments have taken the view that those who commit offences can justifiably be disenfranchised, and that this is a reasonable restriction with a legitimate aim of discouraging crime and promoting civic responsibility. Underpinning the Government's case is the view that prisoners do not deserve the right to vote and that the ban is proportionate because it is imposed in pursuance of legitimate aims, to promote respect for the law and as a justifiable element of punishment.

\section{The undeservingness of prisoners}

The case for disenfranchisement reflects the view that prisoners are undeserving of rights. By breaching the social contract, it is argued, prisoners have forfeited key citizenship rights. In the UK and in many states of the US, convicted prisoners continued to be defined as non-citizens in so far as they lose their right to vote. This also reflects the view in other areas of legislation - for example, in the context of prospective changes in immigration and nationality law - that the right to citizenship needs to be earned through good behaviour [3].

The right to vote has been construed as a revocable privilege rather than a fundamental right, despite nearly a century of universal suffrage. The Government has generally favoured granting privileges awarded for good behaviour, rather than rights, to prisoners, as privileges are not legally enforceable. Privileges can be used as a method of control to maintain order and discipline, whereas rights incur costs in defending alleged breaches and, if they entail a rise in prison standards, in meeting the courts' demands.

The UK Government, and governments in many other jurisdictions, have resisted prisoners' rights claims, including the right to vote, arguing that prisoners do not deserve the same rights as ordinary citizens or special rights because they are prisoners, and specifically do not deserve the right to vote, because they lack moral standing or 'virtue'. While modern concepts of citizenship do not link citizenship explicitly to virtue, they do so indirectly, in so far as they see the prisoner as undeserving of the right to vote, or to stand for public office, or to take part in the government of the country, because of their misdeeds, while the less eligibility principle is used to reinforce the divide between the 
deserving and the undeserving.

This was clear in the Government's submission in Hirst v UK when it argued that those who had breached the basic rules of society should be deprived of:

. . . the right to have a say in the way such rules were made for the duration of their sentence. Convicted prisoners had breached the social contract and so could be regarded as (temporarily) forfeiting the right take part in the government of the country. (para. 50).

The Government also made it clear in its first Consultation Paper that it thinks it is morally right in principle to deny prisoners the right to vote and that it believes that the majority of the public feel the same way (DCA 2006, paras 56, 57). Indeed, it invited comment in support of retention of the status quo (DCA 2006, para. 58). Although no formal or large-scale studies of public attitudes to re-enfranchisement have been undertaken in the UK, when Hirst was decided in October 2005, a poll conducted in Manchester by the Manchester Evening News found that 74 per cent were opposed to giving prisoners the right to vote and 26 per cent were in favour [4].

The Government has argued that this restriction on voting is not excessive given that prisoners have the right to vote restored when they return to the community. It is not permanent, in contrast to some states in the US where felons are disenfranchised for life. The UK Government has also made much of the fact that many other states, including Russia and America, withdraw voting rights from prisoners and, given the exceptionally high incarceration rate of the United States and the fact that ex-offenders in some states are denied the vote on release from prison, means that over 5 million people - are disenfranchised because of criminal convictions. In the United States, 48 states ban sentenced prisoners from voting and constitutional challenges to felon disenfranchisement have so far failed.

Historically, the voting ban represents the notion that prisoners are in a state of 'civil death'. This status goes back to feudal times, where offenders forfeited property rights and family rights on conviction, so property would be taken by the king or the state as an additional punishment. Although the Forfeiture Act 1870 removed most of these sanctions, offender disenfranchisement 
was retained and perpetuated in the UK by subsequent Representation of the People Acts.

Linked to this notion of moral corruption of the prisoner is the belief that denying the offender the right to vote will 'preserve the purity of the ballot box' (Washington $v$ State 75 Ala 582 (1884) at 585). The argument that offenders will sully the purity of the ballot box by irresponsible or incompetent voting, or by electing those unfit to hold office, has been a key influence in United States jurisprudence (see, for example, Shepherd $v$ Trevino, 575 F. 2d. 1110, (5th Cir. 1978), and Bailey v Baronian, 120 R.I.389, 394 A.2d 1338 [1978]). This view was also expressed by the Latvian government in its submission in Hirst (at para. 55). One fear is that felons will elect criminals to important offices, leading to the corruption of public life.

But is the denial of the right to vote those who lack moral virtue justifiable? This argument was rejected by the European Court of Human Rights in Hirst who emphasized that the right to vote was a right and not a privilege. While prisoners lost their right to liberty, their rights under the Convention were not lost by the mere fact of imprisonment. The Court thought that voting was an essential element of the democratic process which should not be casually removed and that there "is no room in the Convention for the old idea of "civic death" that lies behind the ban on convicted prisoners' voting' (at p. 33). Similarly, the Canadian Supreme Court, in Sauvé v Canada No.2) [2002] 3 S.C.R. 519, argued that seeing prisoners as morally unworthy to vote 'runs counter to our constitutional commitment to the worth and dignity of every citizen' which is essential to the legitimacy of the democratic process (McLachlin, CJ at para. 35). The right to vote, the Court said, lay at the heart of Canadian democracy and the blanket ban, in s51(e) of the Canada Elections Act 1985, which denied the vote to federal prisoners serving over two years, was unconstitutional. The Court concluded that this was a regressive and obsolete law which could not be justified in a modern democracy.

To deny the right to vote to the non-virtuous misunderstands the meaning of rights. The UK Government's case is weak because rights do not rest on deservingness, but apply to all, even to those whom we might see as unworthy individuals. Fundamental civil and political rights, such as the right to vote, are universal and do not depend on the moral character of the right-holder. 
The defining feature of a right is that it should not be infringed simply because others might think that the person is morally unworthy and this concept of a right is fundamental to western liberal thought, exemplified by Dworkin's work $(1977,1986)$. It is the mark of a civilized society to accord due process rights at the pre-trial and trial stages to everyone regardless of the crimes of which they are accused, and this respect for rights should also extend to the sentencing and punishment stages. Furthermore, as the right to vote arguably has a special status, it is worthy of greater protection than other rights. To use moral worth as a precondition would be moving on to a potentially politically dangerous slippery slope.

The argument that prisoners do not deserve the benefits of citizenship because of their lack of moral worth is also contradictory, as prisoners are expected to fulfil other civic obligations imposed by the state, such as paying taxes, while in prison. A prisoner whose pay exceeds the appropriate threshold is liable to pay tax and national insurance contributions. So if the government imposes the burden, arguably the prisoner should also have some of the benefits of citizenship, provided that the rights of others are not adversely affected, and in the case of voting, no harms or risk to the public have been shown.

Further, in the original meaning of citizenship in ancient Greece, citizenship was seen as promoting virtue, in imposing duties and obligations on citizens and directing their attention away from private interests, and was not limited to the virtuous. The non-virtuous could retain citizenship provided that they performed their public duties properly (Aristotle, 1992). Participation in political life was itself seen as a means of improving moral behaviour as it ensured that citizens looked towards the good of the polis rather than their own narrow interests. This argument - that participation promotes a sense of civic responsibility - is also found in Mill's work (1861). Similarly, allowing voting rights will encourage prisoners to reflect on their obligations to other members of society.

\section{Disenfranchisement as punishment}

The second strand of the government's argument is that denying prisoners the right to vote has a legitimate aim, namely to punish offenders as well as enhancing civic responsibility and respect for the law. Loss of the right to vote, it is argued, is justifiable and 
reasonable, as it is intended to discourage crime, and is an appropriate element of punishment. But is this denial of a fundamental right of citizenship justifiable as a penal measure? In Hirst the Court accepted that the government's aims to encourage civic responsibility and to impose punishments were legitimate and compatible with Article 3 of Protocol 1, but concluded that the ban was not rationally linked to those aims and was disproportionate and arbitrary. The Court was influenced by the Canadian Supreme Court's ruling in Sauvé $v$ Canada (No.2) [2002] 3 S.C.R. 519 that felon disenfranchisement was unconstitutional because it was an arbitrary and additional punishment.

As a retributivist measure, it is hard to justify as it is not clearly linked to desert, to the degree of harm caused, the seriousness of the offence, or the culpability of the offender, but is a blanket restriction which applies regardless of the seriousness or type of offence, which is why the majority of the court in Hirst found it unacceptable. It is also an arbitrary and variable punishment, as its impact will depend on the timing of an election, which itself depends on the vagaries of political life rather than the prisoner's actions, which makes it inconsistent with retributivism. It is not necessary for the purposes of punishment and is not linked to the gravity of the offence or to the type of offence. It is not, for example, limited to those convicted of electoral crimes. It is also a degrading punishment in so far as it reduces the prisoner to a state of social death. But even if it were accepted as a legitimate punishment, then this could not justify the UK ban, as in Hirst's own case, he was serving a discretionary life sentence, and had already served the part of the sentence intended to punish, and was now serving the extended part of the sentence deemed necessary to protect the public.

Justifying the ban on the grounds of deterrence is also difficult. It is hard to imagine that a prospective offender would be influenced by the prospect of losing voting rights compared to the threat of incarceration. Offenders may also be unaware of this disqualification, although the issue has now received more publicity because of Hirst and subsequent cases.

A justification on the ground of rehabilitation is also problematic. The UK Government has argued that denial of voting rights enhances civic responsibility but it could equally be argued that disenfranchisement perpetuates isolation and social exclusion, 
whereas restoring the vote and participation in the political process would assist rehabilitation by reminding prisoners of the obligations and duties of citizenship and thereby encourage a sense of responsibility. As the Canadian Supreme Court said in Sauvé v Canada (No 2) [2002] 3 S.C.R. 519 there is a connection between having a voice in the making of law and the obligation to obey the law. So the Court was not persuaded by the Canadian Government's argument that a voting ban promotes rehabilitation or that it enhances respect for the law.

A major criterion in modern penal policy is public protection, but can prisoner disenfranchisement be justified on this ground? If an offender had been convicted of voting offences, there might be concerns of future interference with the electoral process, but the ban is much more general and applies to all offenders. To justify the loss of the vote would need an extra element of substantial risk, to override such a fundamental right, which would seem to be lacking in most cases. A voting ban for offenders convicted of voting offences, particularly where there is a risk of re-offending and committing further voting offences, might be justifiable, but this would apply to very few sentenced prisoners. But even for those convicted of voting offences it should apply only for a limited period.

This is not to deny that voting fraud has been a concern in recent UK elections, for example, in the Birmingham local elections in 2004, where Mr Justice Mawrey (2005) said that the evidence of fraud would have 'disgraced a banana republic' [5]. There were also concerns of electoral fraud in the May 2007 local elections, including in Nottingham. A councillor in Slough was convicted by an Election Court of illegal and corrupt practices relating to bogus postal votes in the May 2007 elections and several other individuals have now been convicted of electoral fraud in Slough Central Ward. But these problems are less likely to arise in the prison environment as it is much easier to check on a prisoner's identity than on a postal voter in the community. There are also now new measures to deal with voting fraud and to increase confidence in the integrity of the electoral system, in the new Electoral Administration Act 2006, based on the recommendations of the Electoral Commission (2003). This Act strengthens registration procedures by requiring more information for postal votes, including dates of birth and records of signatures. It creates a new offence of providing false information for the purpose of registration when applying for a postal or proxy vote. 
These measures reduce the risk of personation but postal voting is still seen as the major risk to electoral integrity in UK elections in a recent report by the Council of Europe Parliamentary Assembly [6]. There may also be concerns about block voting which might possibly affect the outcome of an election. An example often given is of the Isle of Wight constituency where the Isle of Wight Prison, created by the amalgamation of Parkhurst, Albany and Camp Hill, has an operational capacity of 1658, is sited within the constituency in which the successful candidate won by a majority of 2826 in the 2001 election, so with a narrower majority the result might have been skewed by the prison vote [7]. However, these issues could be addressed by using the prisoner's former home address for registration. In any case the problem of electoral fraud is not the main rationale of the government's denial of the vote to prisoners.

The case for re-enfranchisement

As we have seen, the loss of the vote is difficult to justify on penological principles, unless we are dealing specifically with electoral fraud. Denying prisoners the right to vote increases their social exclusion and marginalizes prisoners, denying them the opportunity to put pressure on their MP. Re-enfranchisement would arguably have the opposite effect, enhancing their citizen status, giving them a voice and would also further their rehabilitation. These arguments will now be considered.

The symbolic and practical importance of voting

The act of voting is a reaffirmation of citizenship. It is an important element of social participation which reinforces awareness of one's civic duties and obligations. Restoring the vote affirms that individuals are entitled to equal concern and respect, regardless of their past deeds - that they have worth despite their criminal history. Even if the public do not always fully value their own voting rights, in so far as they often will not turn out to vote, this does not detract from the symbolic importance of suffrage.

In the past, citizenship rights, including the right to vote, have been secured through struggle as weak groups have fought to improve their conditions. In England in the 19th century, as E.P. 
Thompson (1968) has shown in The Making of the English Working Class, the demand for suffrage was a crucial element of the realignment of classes in the 1830s. There was intense agitation in 1831-32 over the Reform Bill which symbolized the prospect of social change. Thompson depicts the crisis of 1831-32, through which English society was passing, as one in which revolution was possible. The constitutional and quasi-legal agitation of the people reflected the sharp social and economic inequalities of the time and class conflicts crystallized around the Reform Bill. Its rejection by the House of Lords in October 1831 stimulated widespread demonstrations and unrest. If it had not ultimately been enacted, there could have been a revolution. Reflecting on the public mood of the 1930s, Thompson says:

The vote, for the workers of this and the next decade, was a symbol whose importance it is difficult for us to appreciate, our eyes dimmed by more than a century of the smog of 'two-party parliamentary politics'. It implied, first, egalite: equality of citizenship, personal dignity, worth. (Thompson, 1968: 910, italics in original).

Even then the vote was limited by property qualifications and restricted to men. In the 1832 Act, only one in seven males was eligible to vote. Since then the extension of the franchise has been a result of continued political struggle. The franchise was extended further in 1884, but still only 60 per cent of male voters were eligible. Eventually, the 1918 Representation of the People Act abolished property qualifications and allowed all men over 21 and women over 30 to vote. The denial of the vote to soldiers returning from the war, who had been risking their lives to defend English democracy, but were excluded from its benefits, was clearly an embarrassment for the government. Women over 21 finally won the vote in 1928 after a protracted struggle.

The fact that the demand for universal suffrage has led to imprisonment, hunger strikes and deaths, attests to its significance both symbolic and real, notwithstanding the apathy and complacency of many modern voters, who have elected voluntary disenfranchisement, forfeiting their right to participate in the process of government. The vote is not something to be surrendered lightly, even if there is dissatisfaction with the choice of candidates in a particular election. Of course, in some circumstances refraining from voting may be a political protest reflecting on the lack of integrity of the electoral process, as in 
the case of the Belarus elections in 2000 and in the second round of the Zimbabwean elections in 2008, reflecting the awareness that the democratic process had been violated.

Enfranchisement has a real value as it would give prisoners some influence in the political process. MPs may be more likely to take notice of their views, especially if it is a marginal seat. So it may strengthen prisoners' position in terms of influencing policies which may affect them while in prison, and when they return to the community. Without a vote, they are effectively non-persons, which legitimates the view that prisoners should be forgotten and marginalizes them in the minds of governments and the public. Even if some prisoners may be indifferent to their voting rights, this does not undermine their importance in giving prisoners a voice in public debates and affording them some representation. If this led to improvements in penal regimes, this would benefit all prisoners, including foreign national prisoners who are not entitled to vote.

\section{Voting and re-integration}

For the offender, voting is, in some respects, even more important than for the ordinary citizen, because it is a reminder of one's duties under the social contract. It also reinforces a core value of democracy, namely equality. But denial of voting rights undermines civic respect and respect for the rule of law and thereby erodes the process of prisoner rehabilitation, which should include an understanding of the obligations and burdens of citizenship.

Society may also benefit as enfranchisement promotes the social inclusion and re-integration of offenders. There have been no large scale research studies of the link between voting and offending, but using available statistical data, from a longitudinal study of a cohort of Minnesota public school students, Uggen and Manza (2004: 213) found that there were 'consistent differences between voters and non-voters in rates of subsequent arrest, incarceration and self-reported criminal behaviour'. Clearly, they are not arguing that voting is the key factor in law abiding behaviour, but this association is worth investigating, and would be consistent with the argument advanced above that participation in political life can promote a sense of citizenship.

The right to vote would not solve all the problems of social 
exclusion or guarantee substantive rights, any more than giving women the vote ensured their equal treatment, but it is a positive step as social inclusion may be seen as an important element of citizenship as Marshall (1950) has emphasized. The voting ban also raises disparate impact issues given the disproportionate numbers of black and ethnic minority prisoners in the UK. Similarly in the United States black and Hispanic males are disproportionately incarcerated relative to their numbers in the population, and in Australia a voting ban has a disparate impact on aboriginal communities [8].

\section{Proposals for change}

A number of options are being considered by the UK Government. It now seems clear from the Consultation Paper that the Government is contemplating granting the vote to selected groups of prisoners rather than extending it to all, and considering whether it should be determined by the length of sentence, so the ban applies only to longer term prisoners. Some states do have partial bans depending on the length of sentence. In Belgium, for example, the ban applies to those sentenced to over four months, in Austria over one year and in I taly over five years, while in Greece there is a permanent loss of the right to vote for those sentenced to life imprisonment. In Romania, the ban is dependent on the type and seriousness of the offence, so those convicted of serious offences lose the right to vote. But the problem here is where to draw the appropriate cut-off point. Although this is less arbitrary than the current law, in so far as it is limited to the seriousness of the offence, the problem remains of determining the appropriate point where the line should be drawn for disenfranchisement.

Another option which has been considered is to give sentencers discretion to impose a disqualification, in the light of their knowledge of the crime, and its impact on victims. In Italy, for example, the disqualification from voting is discretionary for these sentenced up to five years, but automatic for those sentenced to five years or more. But a system which gives the sentencer the option to reinstate or withdraw the vote is problematic because it would allow too much discretion to sentencers. It is difficult to see on what criteria the sentencer could make this decision, as most offences will not be voting-related. It is not clear how they would decide whether a voting ban is relevant to the offence, or how they could decide on 
the merits of individual cases. It raises issues unrelated to the original offending behaviour in most cases and increases the burdens on sentencers who are already hard pressed. How could they justify taking a vote away from one offender, but not from another serving a similar term, for an offence of similar gravity? If sentencers were to decide on a case-by-case basis, this would add to the length of the trial. Divergent decisions between offenders convicted of offences of similar gravity would need to be justified, but it is hard to see how coherent non-arbitrary decisions could be made here. Presumably the Sentencing Guidelines Council would be instructed to draft appropriate guidance.

A further option being considered is more plausible, namely that offenders convicted of electoral offences should lose their right to vote. Here a ban might be justified if there is a risk of future offending, and of thereby damaging the democratic process. Germany, for example, imposes a ban on voting rights for those who attack the integrity of the state, the democratic order, and for political insurgents, and this could be Convention compliant, as Strasbourg jurisprudence has justified infringements of Article 3 of Protocol No. 1 on the grounds of abuse of a political position and misconduct in a public office [9]. The Court in Hirst v UK thought there might be situations where a ban would be justified, for example, gross abuse of a public position, or undermining the rule of law and the democratic foundations of society.

The Government is also considering whether voting rights should be given to all those detained in mental hospitals on the same basis as ordinary prisoners. Patients detained in mental hospitals can vote but not if they are offenders detained under criminal powers [10]. The Government is considering relaxing these rules for some offenders. But it could be argued that all patients detained in mental hospitals should still be treated as citizens and to disenfranchise them is inappropriate in modern conditions with more enlightened attitudes. Similar issues of social inclusion apply to this group as to ordinary prisoners and both should be given access to the electoral process [11].

Conclusion: Future developments

Bearing in mind these issues, is change likely in the foreseeable future? The Government could have introduced amendments in the 2006 Electoral Administration Act but did not. There was also 
no reference to this issue in Preparing Britain for the Future: The Government's Draft Legislative Programme 2008/09, published in May 2008. The Government has justified its current position on the grounds that the majority of public are against restoring the vote. Yet the Court in Hirst stressed that public opinion should be given less weight where rights are concerned. The public's lack of sympathy may reflect their ignorance of the advantages of allowing enfranchisement, as well as their general punitiveness, so any changes would need to be carefully presented. It should be made clear to the public that many other states allow voting without any risk of harm and that the voting process would not undermine prison order or security. It would also be relatively easy to administer, as procedures for remand prisoners are in place, as set out in PSO 4650, and it would not be difficult to extend these procedures to encompass sentenced prisoners. The Government may perceive, of course, that there are fewer political advantages in enhancing prisoners' lives or status than in increasing penal austerity and punitiveness, in which case they may consider it more acceptable to the public if just some prisoners are re-enfranchised.

It seems that enfranchisement of all prisoners is unlikely at present, with, at best, some prisoners serving shorter sentences given the vote. If the Government can show that the ban is not automatic and that it has reflected on its reasons for restrictions, it may have done enough to satisfy the European Court of Human Rights that it is Convention compliant and there would be little support from the Opposition for radical change. The leadership of the Conservative Party is opposed to giving the vote to prisoners. However, some Conservative backbenchers and the former Conservative minister Douglas Hurd would support re-enfranchisement, as would the Liberal Democrats and the Scottish National Party. The Chief Inspector of Prisons and some prison governors are also in favour of re-enfranchisement. Support for change has also come from prison reform groups including the Prison Reform Trust $(2004,2007)$, UNLOCK, the National Association for Ex-Offenders, and the Penal Affairs Consortium.

There are also some favourable developments which may improve the prospects for change. It is clear from both Hirst and Sauvé that international rights standards are a much stronger influence on penal conditions than in the past. The right to vote is also protected by Article 25 of the International Covenant on Civil 
and Political Rights. The European Prison Rules are weaker in deferring to state practice, but stipulate that 'Prison authorities shall ensure that prisoners are able to participate in elections, referenda and other aspects of public life, in so far as their right to do so is not restricted by national law' (Rule 24.11).

Moreover, while the Government is right to point to variations in state practice, the general trend worldwide, including Europe, is towards re-enfranchisement, as for example in the Irish Republic. Before the Electoral (Amendment) Act 2006, prisoners did have the right to vote, but only in their constituencies, so in practice they were unable to do so. This Act, introduced after Hirst to ensure Convention compliance, modernizes the law and gives prisoners a right to vote by post. In South Africa, prisoners have been allowed to vote since 1999, following the Constitutional Court's decision in August and another $v$ Electoral Commission and others (1999) (3) SA 1 (CC) and suffrage was viewed by the Court as crucially important in showing that everyone counts. Similarly, in Australia in Roach v Electoral Commissioner [2007] HCA 43, the High Court quashed provisions introduced in 2006 disenfranchising all convicted prisoners because it could find no rational connection between the disqualification and conduct incompatible with participation in the electoral process. However, it preserved the pre-2006 law which restricted disenfranchisement to those serving more than three years. As in the UK, the debate in other jurisdictions has centred on whether allowing prisoners to vote would have adverse effects, or whether enfranchisement actually promotes social cohesion and inclusion, and reinforces the core values of democracy. It is clear from international and domestic human rights jurisprudence that rights extend beyond the prison door, and that any restrictions need to be properly justified but, in the case of a voting ban, as I have argued, it is difficult to justify the current restrictions.

\section{Notes}

[1] Some of the ideas in this article were first presented in papers presented to the Criminal J ustice Research Group at Brunel University in 2006 and to the Sentencing and Punishment stream at the Socio-Legal Studies Association Annual Conference at the University of Kent in April 2007. I am grateful to participants and to the Probation J ournal reviewers for their helpful comments.

[2] See www.echr.coe.int/echr. 
[3] See Home Office (2008).

[4] A review of similar research on this issue in the United States found that 31 per cent of those interviewed favoured re-enfranchisement for serving prisoners (Manza, Brooks and Uggen, 2004).

[5] These issues are further discussed by Stewart (2006).

[6] See Council of Europe Parliamentary Assembly (2007: 38).

[7] Although in the 2005 election the successful candidate won by a larger majority, this may be a legitimate concern.

[8] See Wacquant (2001). About four million prisoners were disenfranchised in the 2004 Presidential election, a large number of whom were African-American. This is significant when the result in Florida was so controversial. The number of citizens is enfranchised because of criminal convictions had risen to 5.3 million by the time of the 2008 Presidential election (see www. sentencingprojct.org). It is estimated that 1 in 7 African-Americans cannot vote because of a felony conviction. See also the Australian challenge to the blanket ban on prisoners' voting, in Roach v Electoral Commissioner [2007] HCA 43. [9] See, for example, Glimmerveen and Hagenbeek $v$ the Netherlands, Apps. Nos. 8348/78 and 8406/78. In MDU v Italy, App. No. 584500/00 23 January 2003, a ban of two years on voting and holding public office was upheld.

[10] See s2 and s4 of the RPA 2000, and s35 of the Electoral Administration Act.

[11] The implications of voting for the social inclusion of individuals with mental health problems are considered further by Nash (2002). The issue of whether individuals detained in mental hospitals should be able to vote will now be considered in a separate consultation process.

\section{References}

Aristotle (1992) Politics. Harmondsworth: Penguin.

Council of Europe Parliamentary Assembly (2007), Application to Initiate a Monitoring Procedure to Investigate Electoral Fraud in the United Kingdom, AS/Mon.

Department for Constitutional Affairs (DCA) (2006) Voting Rights of Convicted Prisoners Detained within the UK, Consultation Paper, 14 December. London: DCA.

Dworkin, R. (1977) Taking Rights Seriously. London, Duckworth.

Dworkin, R. (1986) A Matter of Principle. Oxford University 
Press.

Electoral Commission (2003) Voting for Change. London:

Electoral Commission.

Home Office (2008) The Path to Citizenship: Next Steps in Reforming the Immigration System. London: Home Office.

Manza, J., C. Brooks and C. Uggen (2004) 'Public Attitudes towards Felon Disenfranchisement in the United States', Public Opinion Quarterly 68: 276-87.

Marshall, T.H. (1950) Citizenship and Social Rights. Cambridge: Cambridge University Press.

Mawrey, J. (2005) In the Matter of a Local Government Election for the Bordesley Green Ward of the Birmingham City Council Held on 10th J une 2004; In the Matter of a Local Government Election in the Aston Ward of the Birmingham City Council held on 10th J une 2004, Judgment. London: HM Courts Service.

Mill, J.S. ( 1861) Considerations on Representative Government. London: Parker, Son and Bourn.

Ministry of J ustice (2009) Voting Rights of Convicted Prisoners Detained within the United Kingdom, Second Stage Consultation, Consultation Paper CP6/09.

Nash, M. (2002) 'Voting as a Means of Social Inclusion for People with a Mental Illness', Journal of Psychiatric and Mental Health Nursing 9(6): 697-703.

Office of the Leader of the House of Commons (2008)

Preparing Britain for the future: the

Government's draft legislative programme 2008/09, Cm 7372. London: TSO.

Prison Reform Trust (2004) Barred from Voting: The Right to Vote for Sentenced Prisoners. London: Prison Reform Trust.

Prison Reform Trust (2007) Response of the Prison Reform Trust to the Consultation Produced by the DCA. London, Prison Reform Trust.

Stewart, J. (2006) 'A Banana Republic?', The Investigation into Electoral Fraud by the 
Birmingham Electoral Court', Parliamentary Affairs 59(4): 654-67.

Thompson, E.P. (1968) The Making of the English

Working Class. Harmondsworth: Penguin.

Uggen, C. and J. Manza (2004) 'Voting and Subsequent

Crime and Arrest: Evidence from a Community

Sample', Columbia Human Rights Law Review

36(1): 193-216.

Wacquant, L. (2001) 'Deadly Symbiosis: When Ghetto

and Prison Meet and Mesh', Punishment and

Society 3(1): 95-133.

Cases

Traynor and Fisher [2007] CSOH 78

In Smith v Scott [2007] CSHI9 XA33/04

In Re Toner and Walsh [2007] NIQB 18

Dr Susan Easton is a Reader in Law, Barrister, Professional Liaison Officer, Brunel Law School, Marie Jahoda Building, Brunel University, Cleveland Road, Uxbridge, UB8 3PH, UK. She is co-author of Sentencing and Punishment: the Quest for Justice (Oxford University Press, 2008). Email: Susan.Easton@ brunel.ac.uk 